\title{
Changes to the chemical and microbiological characteristics of Leucaena leucocephala seeds during tempeh fermentation in Pacitan, East Java
}

\author{
1,2,* Ishartani, D., ${ }^{1}$ Sistiani, D., ${ }^{1,2}$ Sari, A.M., ${ }^{1,2}$ Nursiwi, A., ${ }^{1,2}$ Zaman, M.Z. \\ ${ }^{1}$ Department of Food Science and Technology, Faculty of Agriculture, Sebelas Maret University, Jl. \\ Ir.Sutami 36A Surakarta, Central Java, Indonesia 57126 \\ ${ }^{2}$ Halal Research Center, Sebelas Maret University, Jl. Ir. Sutami 36A Surakarta, Central Java, Indonesia \\ 57126
}

\begin{abstract}
Article history:
Received: 7 December 2020

Received in revised form: 9

June 2021

Accepted: 27 June 2021

Available Online: 4 July 2021
\end{abstract}

\section{Keywords:}

Lamtoro tempeh,

Pacitan,

Solid-state fermentation,

Fermentation time

\section{DOI:}

https://doi.org/10.26656/fr.2017.5(S2).009

\begin{abstract}
Lamtoro tempeh is a traditional Indonesian fermented food made from lamtoro (Leucaena leucocephala). In Pacitan, it is usually fermented using usar (a traditional tempeh inoculum made from senggani leaves). The fermentation process takes $42 \mathrm{hrs}$ and during this period, there are changes in the chemical and microbiological characteristics of the lamtoro seeds. To study these changes, samples were collected and tested for chemical characteristics (water content, ash content, dissolved protein, $\mathrm{pH}$, and total acid titration) and microbiological characteristics (the number of fungi, yeast, and lactic acid bacteria) every $6 \mathrm{hrs}$ during the $42 \mathrm{hrs}$ fermentation. During fermentation, the water content increased significantly in the initial $6 \mathrm{hrs}$ of fermentation and then tended to stabilize until the 42-hour. The ash content increased, while the dissolved protein content increased from the 0 -hour to the 36-hour of fermentation but dropped at the 42-hour. The $\mathrm{pH}$ level of the lamtoro tempeh decreased from 0-hour until 30-hour and then increased until the end of the fermentation period. However, the level of total acid titration increased during the lamtoro tempeh fermentation. The growth of fungi, yeast and lactic acid bacteria initially declined but then gradually increased until the end of fermentation (42-hour). The fermentation time was found to affect both the number of microbes and the chemical characteristics of the lamtoro tempeh from the Pacitan area.
\end{abstract}

\section{Introduction}

Tempeh, or tempe in Indonesian, is a traditional Indonesian fermented food (Stephanie et al., 2019). It is generally made from fermented soybeans using Rhizopus $s p$. but can also be produced from other substrates, such as beans, corn, rice, lentils, and barley (Vital et al., 2018). Besides, one of the wide varieties of legumes from which tempeh can be made is lamtoro seeds (Leucaena leucocephala) (Andriati et al., 2018). Fermenting leguminous seeds has several advantages, including reducing non-nutritional factors, improving nutrient digestibility, reducing allergenicity, activating antioxidant activity, increasing the concentration of phenolic compounds, and decreasing the risk of chronic disease (Vital, 2018). Tempeh fermentation produces nutritious and healthy food products that are easy to digest (Nout and Kiers, 2005); it is known for being rich in fiber, isoflavones, vitamin B-12, protein, calcium, and folic acid, and can be easily digested due to the simpler form of protein following the fermentation process
(Babu et al., 2009). Moreover, tempeh is useful for inhibiting the formation of the blood vessels of cancer cells and improving bone health, and is also antihypertensive and acts as an anti-bacterial agent and active antioxidant. During the fermentation of soybean tempeh, it changes its proximate content; for example, there is an increase in water content and dissolved protein, and a decrease in total fat content and total protein content (Chalid et al., 2019).

Soybean tempeh originated on Java Island and subsequently spread across Indonesia; however, the use of lamtoro seed for making tempeh is still limited to a few places in the south of Java Island, such as the Pacitan region in East Java. The producers of lamtoro tempeh in Pacitan are generally located at high elevations and mountainous areas; one of these is Mbah Tukiyem, who is a micro-scale producer. Mbah Tukiyem makes lamtoro tempeh by boiling ripe lamtoro seeds, before grinding, rinsing, soaking, and steaming them. A traditional inoculum, laru, is used for the inoculation 
process. Traditional laru originated from Pacitan and is made from dry senggani leaves, which are mixed with mashed cassava flour. The lamtoro seeds are covered in this mixture before being wrapped in banana stalks covered with fresh senggani leaves and the inoculated seeds are left to incubate for about $42 \mathrm{hrs}$.

The characteristics of lamtoro tempeh are influenced by the various processes of tempeh production, the inoculum used, and fermentation time. Waru, teak, and senggani leaves are all used to wrap the tempeh, dried tempeh, Rhizopus oligosporus isolate, and commercial tempeh inoculums such as "Raprima" are among the inoculums used in tempeh production (Hidayat et al., 2006). The fermentation time has been reported to affect the total protein, dissolved protein, total phenol, and crude fiber content of lamtoro tempeh made using commercial inoculum (Nursiwi et al., 2018). Similarly, the fermentation time also affects trypsin inhibitor activity, mimosine, phytic acid, and the tannin level in lamtoro seeds fermented using the traditional inoculums laru and usar (Slamet and Komari, 1991). Changes have also been noted in microorganisms during soybean fermentation in tempeh production (Nurdini et al., 2015). However, no studies have yet determined what microbiological and chemical changes take place during the fermentation of lamtoro tempeh from Pacitan using traditional inoculums; therefore, this research was conducted to determine the effect of fermentation time on the chemical and microbiological characteristics of lamtoro seeds during fresh Pacitan lamtoro tempeh processing.

\section{Materials and methods}

\subsection{Materials}

Ripe lamtoro seeds (Leucaena leucocephala) and a usar inoculum which utilized senggani leaves were obtained from the micro-scale tempeh producer "Mbah Tukiyem", located in Pacitan, East Java. The materials used for the chemical and microbiological analysis were Lowry solution A, Lowry solution $\mathrm{B}, \mathrm{CuSO}_{4}, \mathrm{NaK}$ tartrate, potato dextrose agar, tartaric acid, malt extract agar, chloramphenicol, de Man Rogosa, and Sharpe agar, and $\mathrm{CaCO}_{3}$. All materials were supplied by Merck, Darmstadt, Germany.

\subsection{Lamtoro tempeh processing}

Lamtoro tempeh processing was conducted according to the standard operating procedure of the micro-scale tempeh producer Mbah Tukiyem, from Pacitan, East Java. Approximately $200 \mathrm{~g}$ of ripe lamtoro seeds were boiled in water containing wood ash for 3 hrs. The seeds were then ground, rinsed, and soaked for
$24 \mathrm{hrs}$, before being ground again and rinsed three times. This process was repeated once. Next, the seeds were steamed for $1 \mathrm{hr}$ and left to stand until they reached room temperature. Finally, the lamtoro seeds were mixed with $55 \%$ usar inoculum, wrapped in paper-plastic laminate, and incubated at $28 \pm 1{ }^{\circ} \mathrm{C}$. The inoculated lamtoro seeds were observed at $0,6,12,18,24,30,36$, and $42 \mathrm{hrs}$.

\subsection{Chemical analysis}

The chemical characteristic under observation were water and ash content (AOAC, 2005), soluble protein content (Lowry et al., 1951), pH (Institute of Medicine, 2003), and total acid titration counted as lactic acid (Aristya et al, 2013).

\subsection{Microbial analysis}

Every 6-hour of fermentation, the inoculated lamtoro seed was sampled for lactic acid bacteria, yeast, and mold enumeration. Approximately $1 \mathrm{~g}$ of each sample was crushed and homogenized in $9 \mathrm{~mL}$ of $0.85 \% \mathrm{NaCl}$ solution then each sample was serially diluted using sterile $0.85 \% \mathrm{NaCl}$ solution.

For Lactic acid bacteria (LAB) enumeration, $1 \mathrm{~mL}$ sample was pour plating on de Man Ragosa Sharpe Agar (Merck) supplemented with $1 \% \mathrm{CaCO}_{3}$ and $0.02 \mathrm{ppm}$ sodium azide then incubated $37^{\circ} \mathrm{C}$ for $48 \mathrm{hrs}$ (Nudyanto dan Zubaidah, 2015). For yeast enumeration, $0.1 \mathrm{~mL}$ sample was spread plating on Malt Extract Agar (Merck) supplemented with $200 \mathrm{ppm}$ chloramphenicol and $0.5 \%$ calcium propionate then incubated $28^{\circ} \mathrm{C}$ for $48 \mathrm{hrs}$ (Ebabhi et al., 2013). For mold enumeration, $0.1 \mathrm{~mL}$ sample was spread plating on Peptone Dextrose Agar (Merck) supplemented with $200 \mathrm{ppm}$ chloramphenicol and $0.1 \%$ tartaric acid then incubated $30^{\circ} \mathrm{C}$ for $48 \mathrm{hrs}$ (Da Silva et al., 2013). The total number of LAB, yeast and mold colonies was expressed as the number of colonies per $\mathrm{mL}(\mathrm{CFU} / \mathrm{mL})$ sample.

\subsection{Statistical analysis}

Statistical analysis was performed using SPSS Version 25 software. The chemical and microbial data were analyzed using one-way ANOVA with a significance level of 5\%, followed by Duncan's multiple range test if a significant difference had been identified.

\section{Results and discussion}

\subsection{Chemical changes}

\subsubsection{Water content}

Water content tended to increase during the fermentation of lamtoro tempeh, as shown in Table 1. The water content of the lamtoro seeds at the 0 -hour was 
Table 1. Chemical characteristics of Pacitan Lamtoro (Leucaena leucocephala) tempeh during fermentation

\begin{tabular}{ccccc}
\hline Sample & $\begin{array}{c}\text { Fermentation } \\
\text { Time (hour) }\end{array}$ & $\begin{array}{c}\text { Water Content } \\
(\% \mathrm{wb})\end{array}$ & $\begin{array}{c}\text { Ash Content } \\
(\% \mathrm{db})\end{array}$ & $\begin{array}{c}\text { Dissolved Protein } \\
\text { Content }(\% \mathrm{db})\end{array}$ \\
\hline & 0 & $62.33 \pm 2.76^{\mathrm{a}}$ & $2.25 \pm 0.13^{\mathrm{a}}$ & $0.04 \pm 0.01^{\mathrm{a}}$ \\
& 6 & $65.40 \pm 2.08^{\mathrm{b}}$ & $2.44 \pm 0.12^{\mathrm{ab}}$ & $0.20 \pm 0.01^{\mathrm{d}}$ \\
Lamtoro & 12 & $63.85 \pm 1.79^{\mathrm{ab}}$ & $2.33 \pm 0.16^{\mathrm{ab}}$ & $0.14 \pm 0.01^{\mathrm{b}}$ \\
Tempeh & 24 & $64.05 \pm 1.23^{\mathrm{ab}}$ & $2.52 \pm 0.16^{\mathrm{b}}$ & $0.22 \pm 0.01$ \\
& 30 & $64.06 \pm 2.39^{\mathrm{ab}}$ & $2.42 \pm 0.17^{\mathrm{ab}}$ & $0.22 \pm 0.01^{\mathrm{e}}$ \\
& 36 & $64.55 \pm 1.49^{\mathrm{ab}}$ & $2.47 \pm 0.21^{\mathrm{b}}$ & $0.26 \pm 0.01^{\mathrm{f}}$ \\
& 42 & $64.48 \pm 0.96^{\mathrm{ab}}$ & $2.44 \pm 0.18^{\mathrm{ab}}$ & $0.19 \pm 0.01^{\mathrm{c}}$ \\
\hline
\end{tabular}

Values are expressed as mean $\pm \mathrm{SD}$. Values with different superscript in the same column are significantly different at 0.05 significance level. db, dry basis; wb, wet basis

$62.33 \%$ (wet basis) and increased to $64.48 \%$ (wet basis) by the end of the fermentation period. An increase in water content during tempeh fermentation has been previously reported by Chalid et al. (2019) and Tahir et al. (2018) in soybean tempeh. Fermentation time is one of the most important factors in the increase in water content (Qomariyah and Deny, 2016); the longer the fermentation time, the higher the water content of the tempeh. This occurs due to the metabolic process and breakdown of macromolecular compounds into simpler compounds during fermentation. According to Steinkraus (1995), during the tempeh fermentation process, water synthesis occurs as a result of the breakdown of carbohydrates by microorganisms (molds).

\subsubsection{Ash content}

Table 1 shows that the ash content slightly increased during the lamtoro tempeh fermentation process; at the 0 -hour of fermentation, the lamtoro seeds contained $2.25 \%$ (dry basis) ash, which increased to $2.44 \%$ (dry basis) by the 42-hour. This trend of an ash increase during fermentation was also observed in soybean and white bean tempeh, fermented using a stock culture of Rhizopus oligosporus in a rice-flour matrix and incubated for $30 \mathrm{hrs}$ (Vital et al., 2018). However, Chalid et al. (2019) found that the ash content in fermented soybean tempeh incubated for $24 \mathrm{hrs}$ decreased from $4.95 \%$ (dry basis) to $1.64 \%$ (dry basis).

\subsubsection{Dissolved protein}

Table 1 shows a change in the dissolved protein content during the lamtoro tempeh fermentation, increasing from $0.04 \%$ (dry basis) at the 0 -hour to $0.26 \%$ at the 36 -hour before falling to $0.19 \%$ (dry basis) at the 42-hour. The rising dissolved protein content in the tempeh was caused by the Rhizopus sp., which produced protease (Hsiao et al., 2014), an enzyme that catalyzes the hydrolysis of peptide bonds into amino acids (LópezOtín and Bond, 2008). Rhizopus oryzae triggered proteolytic activity, breaking down protein into amino acids and short-chain polypeptide (Cempaka et al., 2018; Nout and Kiers, 2005). The increased dissolved protein content during the fermentation of jack bean tempeh was accompanied by a decrease in peptide bonds by protease microbes (Andriati et al., 2018). A study by Chalid et al. (2019) also reported an increase in dissolved protein from 75.19 part per million (ppm) to $236.31 \mathrm{ppm}$ during the fermentation of soybean tempeh using the commercial inoculum "Raprima" with 48 hrs' incubation. An increase in the dissolved protein content was also found during the fermentation of lamtoro seeds using a stock culture of Rhizopus oryzae for $48 \mathrm{hrs}$ (Komari, 1999). In addition, Nursiwi et al. (2018) found that dissolved protein rose during lamtoro tempeh fermentation using the commercial inoculum "Raprima" as a starter. However, protein content could also decrease, as Rhizopus sp. mold uses some amino acids to gain nitrogen, triggering their growth in the fermentation process (Astuti et al., 2000).

\subsection{4 $\mathrm{pH}$ and total acid titration changes}

The $\mathrm{pH}$ value fluctuated during the lamtoro tempeh fermentation but generally decreased (Table 2); the $\mathrm{pH}$ at the 0 -hour was 7.11 and dropped to 5.91 by the 42-hour. The $\mathrm{pH}$ was also found to decrease during the fermentation process of soybean tempeh, from 6.73 at the 0-hour to 6.65 at the 48-hour (Nurdini et al., 2015), and jack bean tempeh, from 6.34 at the 0 -hour to 6.16 at the 36-hour (Andriati et al., 2018). The $\mathrm{pH}$ drop was due to the growth of LAB and mold during the tempeh fermentation. LAB produces lactic acid, which decreases the $\mathrm{pH}$ of the tempeh and inhibits the growth of rotting microorganisms (Feng, 2005). In contrast, the increase in $\mathrm{pH}$ during the fermentation of soybean tempeh fermented using the traditional starter culture laru is presumed to be caused by the proteolytic activity of the molds, which can produce amino acids, contributing to a rise in pH (Nurdini et al., 2015). Komari (1999) reported an increase in the $\mathrm{pH}$ level from 5.25 to 6.03 during the 48-hour fermentation of lamtoro tempeh, using a stock 
Table 2. pH and total acid titration of Pacitan Lamtoro (Leucaena leucocephala) tempeh during fermentation

\begin{tabular}{cccc}
\hline Sample & Fermentation Time (hour) & $\mathrm{pH}$ & Total Acid Titration (\% as lactic acid) \\
\hline 0 & $7.11 \pm 0.04^{\mathrm{f}}$ & $0.10 \pm 0.01^{\mathrm{a}}$ \\
& 6 & $6.35 \pm 0.03^{\mathrm{e}}$ & $0.13 \pm 0.01^{\mathrm{b}}$ \\
Lamtoro & $5.70 \pm 0.04^{\mathrm{c}}$ & $0.15 \pm 0.03^{\mathrm{ab}}$ \\
Tempeh & 18 & $5.58 \pm 0.03^{\mathrm{a}}$ & $0.17 \pm 0.03^{\mathrm{ab}}$ \\
& 24 & $5.70 \pm 0.07^{\mathrm{c}}$ & $0.15 \pm 0.03^{\mathrm{ab}}$ \\
& 30 & $5.64 \pm 0.08^{\mathrm{ab}}$ & $0.19 \pm 0.06^{\mathrm{b}}$ \\
& 36 & $5.67 \pm 0.05^{\mathrm{bc}}$ & $0.18 \pm 0.06^{\mathrm{b}}$ \\
& 42 & $5.91 \pm 0.05^{\mathrm{d}}$ & $0.18 \pm 0.03^{\mathrm{b}}$
\end{tabular}

Values are expressed as mean \pm SD. Values with different superscript in the same column are significantly different at 0.05 significance level.

culture of Rhizopus oryzae as the starter inoculum. Fermentation is also known to cause changes in several organic acids, such as acetic acid, oxalic acid, citric acid, and succinic acid, which affect $\mathrm{pH}$, as observed in soybean tempeh fermentation using a Rhizopus starter (Mo et al., 2013).

The pattern in $\mathrm{pH}$ change during the fermentation of Pacitan lamtoro tempeh slightly differed from that of the total acid titration change, which tended to increase throughout the fermentation period, from $0.10 \%$ at the 0 hour to $0.18 \%$ at the 42 -hour (Table 2). A similar pattern was observed by Komari (1999) during lamtoro tempeh fermentation using a stock culture of Rhizopus oryzae and soybean tempeh fermentation using a traditional inoculum, laru (Nurdini et al., 2015). The rise in total acid titration occurred as the $\mathrm{LAB}$ produced lactic acid, which is LAB's main metabolite produced in the carbohydrate metabolism; lactic acid could lower the $\mathrm{pH}$ of the substrate, increasing the total acidity as well as being antibacterial (Feng et al., 2005).

\subsection{Microbiological changes}

Many factors, such as substrate, $\mathrm{pH}$ value, and temperature, can affect microbe activity (Dewi et al., 2004). Table 3 shows the mold, yeast, and LAB growth during the lamtoro tempeh fermentation. Mold and yeast number dropped in the first $6 \mathrm{hrs}$ before increasing, from hour 30 for mold and hour 12 for yeast, until the end of the fermentation period. A study by Chalid et al. (2019) on the fermentation of soybean tempeh reported that Rhizopus sp. number increased initially at the 18 -hour and continued to increase the next hrs, reaching optimum growth at the 24-hour of fermentation. Nurdini et al. (2015) reported a similar trend in mold growth in soybean tempeh produced by two home industries; following an initial decrease, there was an increase at hrs 24 and 48 of fermentation. In contrast, yeast numbers increased constantly until hour 48 of fermentation. Rhizopus oryzae can grow in environments with a $\mathrm{pH}$ ranging from 4-9, but its optimal growth is at a $\mathrm{pH}$ of 3.4 -5.5 (Hernandez et al., 2017). Compared to bacteria and mold, yeast can grow better at a range of $\mathrm{pH}$ levels and generally demonstrates optimal growth in conditions with a pH of 4-4.5 (Kurztman and Jack, 1998). The $\mathrm{pH}$ level of the lamtoro tempeh in this research was intended to be ideal for both mold and yeast growth (Table 2). Generally, the longer the fermentation, the better the mold growth; this was characterized by mycelia growth that covered the surface of the tempeh, creating a compact texture.

Meanwhile, the LAB number increased until the 18hour, decreased at the 24-hour, and then remained stable until the 42-hour of fermentation (Table 3). According to Bagenda et al. (2008), LAB Pediococcus pentosaceus

Table 2. $\mathrm{pH}$ and total acid titration of Pacitan Lamtoro (Leucaena leucocephala) tempeh during fermentation

\begin{tabular}{ccccc}
\hline Sample & $\begin{array}{c}\text { Fermentation Time } \\
\text { (hour) }\end{array}$ & $\begin{array}{c}\text { Mold } \\
(\log \text { CFU/mL) }\end{array}$ & $\begin{array}{c}\text { Yeast } \\
(\log \text { CFU/mL) }\end{array}$ & $\begin{array}{c}\text { LAB } \\
(\log \text { CFU/mL })\end{array}$ \\
\hline 0 & $4.60 \pm 0.17^{\mathrm{b}}$ & $4.48 \pm 0.05^{\mathrm{b}}$ & $5.97 \pm 0.22^{\mathrm{a}}$ \\
& 6 & $3.53 \pm 0.09^{\mathrm{a}}$ & $3.85 \pm 0.17^{\mathrm{a}}$ & $6.18 \pm 0.17^{\mathrm{a}}$ \\
Tamtoro & 12 & $3.79 \pm 0.16^{\mathrm{a}}$ & $4.59 \pm 0.09^{\mathrm{b}}$ & $8.84 \pm 0.02^{\mathrm{b}}$ \\
Tempeh & 18 & $3.69 \pm 0.07^{\mathrm{a}}$ & $5.44 \pm 0.01^{\mathrm{c}}$ & $10.00 \pm 0.18^{\mathrm{c}}$ \\
& 24 & $3.70 \pm 0.07^{\mathrm{a}}$ & $5.90 \pm 0.18^{\mathrm{d}}$ & $9.80 \pm 0.06^{\mathrm{c}}$ \\
& 30 & $4.75 \pm 0.07^{\mathrm{b}}$ & $6.04 \pm 0.01^{\mathrm{d}}$ & $9.82 \pm 0.19^{\mathrm{c}}$ \\
& 36 & $5.79 \pm 0.05^{\mathrm{c}}$ & $6.46 \pm 0.03^{\mathrm{e}}$ & $9.91 \pm 0.05^{\mathrm{c}}$ \\
& 42 & $5.86 \pm 0.14^{\mathrm{c}}$ & $6.81 \pm 0.34^{\mathrm{e}}$ & $9.77 \pm 0.01^{\mathrm{c}}$ \\
\hline
\end{tabular}

Values are expressed as mean \pm SD. Values with different superscript in the same column are significantly different at 0.05 significance level. LAB, lactic acid bacteria. 
grows optimally in an environment with a $\mathrm{pH}$ ranging from 5-6 and can tolerate a $\mathrm{pH}$ of 4.5-7.5. This kind of environment was found in the lamtoro tempeh fermentation (Table 2). LAB in tempeh can grow with little or even no oxygen. Therefore, the relatively few pores on the tempeh wrapper would trigger the increase of microbes, especially LAB. LAB and yeast played an essential role in improving the quality of the tempeh produced (Kustyawati, 2009).

\section{Conclusion}

In this study, fermentation time was found to affect the microbiological and chemical characteristics of lamtoro seeds during the fermentation of lamtoro tempeh inoculated with a traditional inoculum, usar, from Pacitan. During the 42-hour fermentation of lamtoro tempeh, an increase was observed in water, ash, dissolved protein, total acid titration, mold, yeast, and $\mathrm{LAB}$, while $\mathrm{pH}$ was found to decline. Further research on the effect of fermentation time for lamtoro tempeh on the level of mimosine, a toxic compound present in lamtoro seeds, is necessary to ensure the right fermentation time to produce lamtoro tempeh which is safe for consumption.

\section{Conflict of interest}

The authors declare no conflict of interest.

\section{Acknowledgments}

The research work was funded by The Ministry of Research, Technology, and Higher Education of Republic of Indonesia (Grant No. 098/SP2H/LT/DRPM/ IV/2017).

\section{References}

Andriati, N., Anggrahini, S., Setyaningsih, W., Sofiana I., Pusparasi, D.A. and Mossberg, F. (2018). Physicochemical Characterization of Jack Bean (Canavalia ensiformis) Tempeh. Food Research, 2 (5), 481-485. https://doi.org/10.26656/fr.2017.2 (5). 300

AOAC. (2005). Official Methods of Analysis of the Association of Official Analytical Chemists. Washington D.C., USA: AOAC International.

Aristya, A.L., Legowo, A.M., Al-Baarri, A.N. (2013). Total Asam, Total Yeast, dan Profil Protein Kefir Susu Kambing dengan Penambahan Jenis dan Konsentrasi Gula yang Berbeda. Jurnal Pangan dan Gizi, 4(7), 39-47. [In Bahasa Indonesia].

Astuti, M., Meliala A., Dalais F.S., and Wahlqvist, M.L. (2000). Tempe, A Nutritious and Healthy Food from
Indonesia. Asia Pacific Journal of Clinical Nutrition, 9(4), 322-325. https://doi.org/10.1046/j.14406047.2000.00176.x

Babu, P.D., Bhakyaraj R. and Vidhyalaksmi, R. (2009). A Low Cost Nutritious Food "Tempeh" - A Review. Journal of Dairy and Food Sciences, 4(1), 22-27.

Bagenda, D.K., Hayashi K., Yamazaki, K. and Kawai, Y. (2008). Characterization of An Antimicrobial Substances Produced by Pediococcus pentosaceus Iz3.13 Isolated from Japanese Fermented Marine Food. Fisheries Science, 74, 439-448. https:// doi.org/10.1111/j.1444-2906.2008.01542.x

Cempaka, L., Naila, E., Ardiansyah, Handoko, D.H. and Astuti, M.A. (2018). Proximate Composition, Total Phenolic Content, and Sensory Analysis of Rice Bran Tempeh. Makara Journal of Science, 22(2), 8994. https://doi.org/10.7454/mss.v22i2.9616

Chalid, S.Y., Hermanto, S. and Rahmawati, A. (2019). Angiotensin Converting Enzyme Inhibitor Activity of the Soybean Tempeh Protein as Functional Food. International Journal of GEOMATE, 16(56), 73-78. https://doi.org/10.21660/2019.56.4583

Da Silva, N., Taniwaki, M.H., Junqueria, V.C.A., Silviera, D. Maristela, D. and Gomes, R.A. (2013). Microbiological Examination Methods of Food and Water: A Laboratory Manual. London, United Kingdom: CRC Press.

Dewi, C., Purwoko, T. and Pangastuti, A. (2004). Production of Reduction Sugar by Rhizopus oryzae from Substrate Rice Bran. Bioteknologi, 2(1), 21-26.

Ebabhi, A.M., Adekunle, A.A., Okunowo, W.O. and Osuntoki, A.A. (2013). Isolation and Characterization of Yeast Strains from Local Food Crops. Journal of Yeast and Fungal Research, 4(4), 38-39.

Feng, X.M., Eriksson, A.R. and Schnürer, J. (2005). Growth of Lactic Acid Bacteria and Rhizopus Oligosporus during Barley Tempeh Fermentation. International Journal of Food Microbiology, 104(3), 249-256. https://doi.org/10.1016/ j.ijfoodmicro.2005.03.005

Hernandez, L.L., Toro, C.R., Ruiz H.A., Valdes, J.A.A, Gonzales M.A.A., Herrera, R.R. and Aguilar, C.N. (2017). Rhizopus oryzae - Ancient Microbial Resource with Importance in Modern Food Industry. International Journal of Food Microbiology, 257 (18), $\quad 110-127 . \quad$ https://doi.org/10.1016/ j.ijfoodmicro.2017.06.012

Hidayat, N., Padaga M.C. and Suhartini S. (2006). Mikrobiologi Industri. Yogyakarta: Andi Offset. [In Bahasa Indonesia].

Hsiao, N.W., Chen, Y., Kuan, Y.C., Lee, Y.C., Lee, 
S.K., Chan, H.H. and Kao, C.H. (2014). Purification and Characterization of An Aspartic Protease from the Rhizopus oryzae Protease Extract, Peptidase R. Electronic Journal of Biotechnology, 17(2), 89-94. https://doi.org/10.1016/j.ejbt.2014.02.002

Institute of Medicine. (2003). Food Chemicals Codex. $5^{\text {th }}$ ed. Washington, DC., USA: The National Academies Press.

Komari. (1999). Fermentation Process of Lamtoro-Gung Seed with Rhizopus oryzae. Journal of Microbiological Indonesia, 4(1), 19-21.

Kurztman, C.P. and Fell, J.W. (1998). The Yeast: A Taxonomic Study. $4^{\text {th }}$ ed. New York, USA: Elsevier.

Kustyawati, M.E. (2009). Study of the Role of Yeast in Making Tempeh. AGRITECH, 29(2), 64-70.

López-Otín, C and Bond, J.S. (2008). Proteases: Multifunctional Enzymes in Life and Disease. Journal of Biological Chemistry, 283(45), 30433 30437. https://doi.org/10.1074/jbc.R800035200

Lowry, O.H., Rosenbourgh, N.J., Farr, A.L. and Randall, R.J. (1951). Protein Measurement with the Folin Phenol Reagent. Journal Biological Chemistry, 193 (1), 265-275. https://doi.org/10.1016/S0021-9258 (19)52451-6

Mo, H., Kariluoto, S., Piironen, V., Zhu, Y., Sanders, M.G., Vincken, J.P., Wolkers-Rooijackers, J. and Nout, M.J.R. (2013). Effect of Soybean Processing on Content and Bioaccessibility of Folate, Vitamin B12 and Isoflavones in Tofu and Tempe. Food Chemistry, 141(3), 2418-2425. https:// doi.org/10.1016/j.foodchem.2013.05.017

Nout, M.J.R. and Kiers, J.L. (2005). Tempe Fermentation, Innovation and Functionality: Update into the Third Millennium. Journal of Applied Microbiology, 98(4), 789-805. https:// doi.org/10.1111/j.1365-2672.2004.02471.x

Nudyanto, A. and Zubaidah, E. (2015). Isolasi Bakteri Asam Laktat Penghasil Eksopolisakarida dari Kimchi. Jurnal Pangan dan Agroindustri, 3(2), 732748.

Nurdini, A.L., Nuraida, L., Suwanto, A. and Suliantari. (2015) Microbial Growth Dynamics during Tempe Fermentation in Two Different Home Industries. International Food Research Journal, 22(4), 16681674.

Nursiwi, A., Ishartani, D., Sari, A.M. and Nisyah, K. (2018). Perubahan Kadar Protein, Kadar Serat, dan Kadar Fenol Selama Fermentasi Tempe Lamtoro Leucaena leucocephala). Seminar Nasional dalam Rangka Dies Natalis UNS Ke 42 Tahun 2018, 2(1), 81 - 87. [In Bahasa Indonesia].

Qomariyah, N. and Utomo, D. (2016). Pengaruh
Penambahan Biji Lamtoro Gung (Leucaena leucocephala) pada Proses Fermentasi Tempe. Jurnal Teknologi Pangan, 7(1), 46-56. [In Bahasa Indonesia]. https://doi.org/10.35891/tp.v7i1.504

Slamet, D.S. and Komari. (1991). Evaluation of Safety Aspects of the Diets Prepared from Processed Lamtoro-Gung (Leucaena leucocephala) Seeds in Albina Rats. Presented at 6th Asian Congress of Nutrition 16-19 September 1991. Kuala Lumpur.

Steinkraus, K.H. (1995). Handbook of Indigenous Fermented Foods. 2nd ed. Boca Raton, USA: CRC Press.

Stephanie, Kartawidjajaputra, F., Silo, W., Yogiara, Y. and Suwanto, A. (2019). Tempeh Consumption Enhanced Benefical Bacteria in Human Gut. Food Research, 3(1), 57-63. https://doi.org/10.26656/ fr.2017.3(1).230

Tahir, A., Anwar, M., Mubeen, H. and Raza, S. (2016). Evaluation of Physicochemical and Nutritional Contents in Soybean Fermented Food Tempeh by Rhizopus oligosporus. Journal of Advances in Biology and Biotechnology, 17(1), 1-9. https:// doi.org/10.9734/JABB/2018/26770

Vital, R.J., Bassinello, P.Z., Cruz, Q.A., Carvalho, R.N., De Paiva, J.M. and Colombo, A.O. (2018). Production, Quality, and Acceptance of Tempeh and White Bean Tempeh Burgers. Foods, 7(9), 136. https://doi.org/10.3390/foods7090136 